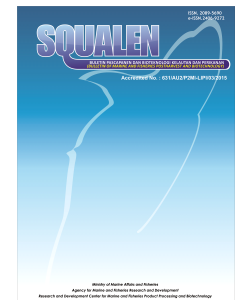

\title{
Influence of Salinity on Growth and Phycoerythrin Production of Rhodomonas salina
}

\author{
Endar Marraskuranto ${ }^{1,2}$, Tri J. Raharjo ${ }^{1,3^{*}}$, Rina S. Kasiamdari ${ }^{1,4}$, and Tri R. Nuringtyas ${ }^{1,4}$ \\ ${ }^{1}$ Biotechnology Study Program, Graduate School, Gadjah Mada University \\ Jalan Teknika Utara, Sleman, DI Yogyakarta, Indonesia \\ ${ }^{2}$ Research and Development Center for Marine and Fisheries Product Processing and Biotechnology, \\ Jalan KS. Tubun Petamburan VI, Slipi, Jakarta Pusat 10260, Indonesia \\ ${ }^{3}$ Department of Chemistry, Faculty of Mathematics and Natural Sciences, Gadjah Mada University, \\ Jalan Bulaksumur, Sleman, DI Yogyakarta, Indonesia
}

${ }^{4}$ Department of Biology, Faculty of Biology, Gadjah Mada University, Jalan Bulaksumur, Sleman, DI Yogyakarta, Indonesia

Article history:

Received: 28 October 2018; Revised: 26 November 2018; Accepted: 13 Desember 2018

\begin{abstract}
Microalgae is a photoautotroph organism capable of producing various photosynthetic pigments with diverse beneficial properties. Rhodomonas salina, a Cryptophyte cell, contains only phycoerythrin as its phycobiliprotein pigment. The effects of salinity on growth and phycoerythrin concentration were investigated. Microalgae $R$. salina were grown in natural sea water with salinity of $33 \%$ and $50 \%$. The microalgae was batch-cultured in $\mathrm{f} / 2 \mathrm{medium}$ at light irradiation of 1100 lux, temperature of $24-26{ }^{\circ} \mathrm{C}$, and photoperiode of $12 \mathrm{~h}: 12 \mathrm{~h}$. The microalgae cell density was directly calculated using haemacytometer. The concentration of phycoerythrin was determined by spectrophotometric method. The cell density and phycoerythrin concentration were monitored every 4 days for 20 days of cell growth. Results showed that salinity did not affect significantly both on growth and phycoerythrin concentration extracted from $R$. salina biomass $(p>0.05 ; \alpha=0.05)$. At both salinity, maximum phycoerythrin concentration were reached on day 8 . There was a positive correlation between cell density and phycoerythrin concentration from day 1 to day 8 of cell growth. Microalgae $R$. salina which was grown in natural seawater with salinity of $33 \%$ achieved the highest cell density of $8.4 \times 10^{5}$ cells $/ \mathrm{mL}$ and the phycoerythrin concentration of $0.19 \mu \mathrm{g}$. $10^{-5}$ cell on day 8 of the culture. The highest phycoerythrin concentration was obtained on day 16 of the culture i.e 0.27 $\mu \mathrm{g} .10^{-5}$ cell.
\end{abstract}

Keywords: cell density, growth media, phycoerythrin, Rhodomonas salina, salinity

\section{Introduction}

Phycoerythrin (PE) is a type of phycobiliprotein, a water-soluble protein-pigment complex. The color of $\mathrm{PE}$ pigment is derived from chromophore-containing compounds categorized as phycobilin. Phycoerythrin structure is a combination of linier tetrapyrrole chain compound (phycobilin) and a polypeptide chain that are connected via a thiol bridge to the cysteine residue in the polypeptide chain. A phycoerythrin compound has a combination of two phycobilins which one phycobilin molecule can have five different types of structures depending on the source. Based on its specific spectral characteristics, the type of phycoerythrin is usually distinguished by adding one letter, either a capital or small cap, in front of the word phycoerythrin as a prefix. Types and sources of phycoerythrin are B-phycoerythrin (545-546 nm; 563$565 \mathrm{~nm} ; 498 \mathrm{~nm}$ (shoulder); red algae), b-phycoerythrin ( $545 \mathrm{~nm} ; 563 \mathrm{~nm}$; red algae), R-phycoerythrin (493$498 \mathrm{~nm}$; 534-545 nm; 564-568 nm; red algae), rphycoerythrin (498 nm; $542 \mathrm{~nm} ; 560 \mathrm{~nm}$; red algae), and C-phycoerythrin (562-565 nm; cyanobacteria)(de Marsac, 2003; Toole \& Allnutt, 2003). Phycoerythrin derived from Rhodomonas salina is designated as Cryptophyte-Phycoerythrin (Cr-PE) or Cr-PE545 because it has a maximum absorption at $545 \mathrm{~nm}$ wavelength (Toole \& Allnutt, 2003).

One Cr-PE molecule contains two phycobilins namely phycoerythrobilin (PEB) and 15,16dihydrobiliverdin (DBV)(Toole \& Allnutt, 2003).

${ }^{*}$ Corresponding author.

E-mail: trijr_mipa@ugm.ac.id 
Therefore, Cr-PE absorbs yellow-green color of the color spectrum and shows red to pink color character. When compared to other phycobiliproteins-containing algae, $R$. salina which is classified as Cryptophyte contains only PE as its phycobiliprotein, so its accumulation within cells does not compete with other phycobiliproteins such as phycocyanin and allophycocyanin (Lee, 2008).

According to several studies, PE production from Rhodomonas sp. is influenced by nitrate concentration, photon flux density (light intensity), and temperature (Bartual, Lubián, Gálvez, \& Niell, 2002; Chaloub, Motta, de Araujo, de Aguiar, \& da Silva,, 2015; da Silva, Lourenco, \& Chaloub, 2009; Vu et al., 2015). Compared to chlorophyll, other pigments or accessories pigments, i.e. PE concentration extracted from the cultivated microalgae under optimum growth conditions is still very low (Mulders, Lamers, Martens, \& Wijffels, 2014). As a result, the accessories pigment production from microalgae will encounter many challenges economically. Therefore, the content of these pigments in microalgae cells should be increased so that their production can compete economically with synthetic pigments. Attempts can be made by culturing them in a particular growth condition, such as the application of adverse growth or extreme environmental conditions, i.e. high salinity, high light intensity, extreme temperature and/or nutrient deprivation (Mulders et al., 2014). This growth condition has been successfully applied on caroteneproducing microalgae such as Dunaliella salina (Lamers, Janssen, De Vos, Bino, \& Wijffels, 2008).

Attempts in using extreme environmental conditions has been conducted on Rhodomonas sp.'s culture condition in term of its growth and phycoerythrin production. da Silva et al. (2009) found that there was a rapid decline in $\mathrm{N}$-containing compound such as hydrosoluble proteins and photosynthetic pigments and ultimately caused an almost complete loss of PE in a nitrogen starvation culture. Meanwhile, attempting to grow $R$. salina in high intensity of light (above $300 \mu \mathrm{mol}$ photon $\mathrm{m}^{-2} \mathrm{~s}^{-1}$ ) caused a photoinhibition on its growth and a decrease in photosynthetic activities (Bartual et al., 2002). Study on Rhodomonas sp. growth and phycoerythrin production in a high salinity environment has not been reported. Although Jepsen et al. (2018) proved that $R$. salina strain K-1487 can be cultivated in a wide range of salinity $(0-65 \%$ ), they did not observe the photosynthetic pigment content in that range. Jepsen et al. (2018) also showed that salinity influenced the specific growth rate on $R$. salina strain $\mathrm{K}-1487$. The specific growth rate of $R$. salina increased at the salinity of $0-29 \%$. On the contrary, the rate decreased at the salinity of $29-65 \%$. Thus, the objective of this study was to observe the growth of $R$. salina in 33 and $50 \%$ salinity and to estimate the concentration of PE produced by $R$. salina during its growth.

\section{Materials and Methods}

\subsection{Material}

Microalgae $R$. salina were obtained from the Institute for Mariculture Research and Fisheries Extension (IMRAFE), Gondol, Bali. The f/2 medium was produced from mineral salts such as $\mathrm{NaNO}_{3}$ (Merck), $\mathrm{NaH}_{2} \mathrm{PO}_{4} \cdot 2 \mathrm{H}_{2} \mathrm{O}$ (Merck), $\mathrm{FeCl}_{3} \cdot 6 \mathrm{H}_{2} \mathrm{O}$ (Merck), $\mathrm{Na}_{2}$ EDTA $2 \mathrm{H}_{2} \mathrm{O}$ (Merck), $\mathrm{MnCl}_{2} \cdot 4 \mathrm{H}_{2} \mathrm{O}$ (Merck), $\mathrm{ZnSO}_{4} \cdot 7 \mathrm{H}_{2} \mathrm{O}$ (Merck), $\mathrm{CoCl}_{2} \cdot 6 \mathrm{H}_{2} \mathrm{O}$ (Merck), $\mathrm{CuSO}_{4} \cdot 5 \mathrm{H}_{2} \mathrm{O}$ (Merck), $\mathrm{Na}_{2} \mathrm{MoO}_{4} \cdot 2 \mathrm{H}_{2} \mathrm{O}$ (Merck). This medium also includes vitamin mix which composed of thiamine. $\mathrm{HCl}$ (vitamin B1) (Merck) and cyanocobalamin (vitamin B12) (Merck). Water level 1 is of ICP-MS grade.

\subsection{Methods}

\subsubsection{Cultivation of $R$. salina microalgae}

Microalgae were batch-cultured in two culture conditions with a working volume of $300 \mathrm{~mL}$ (Table 1). Before starting the experiments, $R$. salina was cultured in a 500-mL erlenmeyer, with 0.2-mM filtered seawater with a modified f/2 medium (Guillard, 1975 in Andersen, Berges, Harrison, \& Watanabe, 2005), at optimal growth condition according to Chaloub et al. (2015). In both cultures (containing $\mathrm{f} / 2$ medium and inoculum), microalgae were grown in natural seawater except that the salinity of $\mathrm{C} 1$ culture was modified. The modification was made by mixing natural sea water and ASW Salt Mix + so that the salinity reached $50 \%$. All growth media were sterilized using autoclave at $121^{\circ} \mathrm{C}$ for $15 \mathrm{~min}$. All cultures were performed in triplicates.

Subsequently, inoculum solution of $60 \mathrm{~mL}$ with a cell density of approximately $1.0 \times 10^{6}$ cells $/ \mathrm{mL}$ was diluted aseptically into culture erlenmeyer containing $240 \mathrm{~mL}$ of culture media, so that the initial cell density of microalgae in all cultures was $2.0 \times 10^{5} \mathrm{cells} / \mathrm{mL}$. The culture conditions were set up according to optimal condition obtained by Chaloub et al. (2015). In order to avoid contamination, the observation of cell density was performed once every 4 days from a $1-\mathrm{mL}$ culture solution and the cell density calculation was performed manually using a haemocytometer. For each culture, growth rate $(m)$ was calculated using Equation (1)

$$
\mu=\frac{\log _{e} N_{t}-\log _{e} N_{0}}{\Delta t}=\frac{2.3}{\Delta t}\left(\log _{10} N_{t}-\log _{10} N_{O}\right)(1)
$$


Note:

$\mathrm{N}_{0}=$ cell density at the beginning of a time interval;

$\mathrm{Nt}=$ cell density at the end of the time interval;

$\Delta t=$ the length of th time interval $(\mathrm{tt}-\mathrm{t} 0)$.

\subsubsection{Analyses of phycoerythrin}

The extraction of phycoerythrin (PE) was performed in accordance to Lawrenz, Fedewa, \& Richardson (2011). A wet $R$. salina biomass concentrated from one mililitre culture solution was used as sample. The wet biomass was macerated in $0.1 \mathrm{M}$ phosphate buffer solution $(\mathrm{pH}=6.0)$. The solution was subjected to freeze-thawing extraction, freezing for $2 \mathrm{~h}$ and refrigeration for $24 \mathrm{~h}$. Phycoerythrin-content supernatant was concentrated in refrigerated sentrifuge $\left(10,000 \times \mathrm{g} ; 4^{\circ} \mathrm{C} ; 10 \mathrm{~min}\right)$. The phycoeryhtrin solutions were placed into 96 -well plate to measure the absorbance spectrophotometrically at $280,455,545$, 564, 592, and $750 \mathrm{~nm}$. The estimation of PE concentration was calculated using formula described in Thoisen, Hansen, and Nielsen (2017). The PE concentration was calculated according to Beer and Eshel (as cited in Thoisen et al. (2017))(Eq. 2). Phycoerythrin concentration was expressed as $\mu \mathrm{g} \cdot 10^{-5}$ cell to indicate the amount of phycoerythrin per microalgae cell density.

$P E\left(\frac{\mu g}{m L}\right)=\left[\left(\left(A_{564}-A_{592}\right)-\left(A_{455}-A_{592}\right) \times 0.2\right) \times 0.12\right] \times 1000(2)$

Note:

$\mathrm{PE}=$ phycoerythrin

$A=$ absorption at the indicated wavelengths

\subsubsection{Statistical analysis}

All data measurements are shown as mean +/standard deviation $( \pm S D)$ of three independent replicates. Data were tested for normal distribution (Kolmogorov-Smirnoff goodness of fit test) before being analyzed by ANOVA. The results were analyzed by one-way analyses of variance (ANOVA) with $\alpha=0.05$, using SPSS 15.0. Least Significant Difference (LSD) post hoc test was performed for in depth analysis of the differences between individual treatment.

\section{Results and Discussion}

\subsection{Rhodomonas salina Growth under Different Salinity}

This study used batch culture type to grow $R$. salina because it is easy to manipulate the growth condition of the microalgae (Wood, Everroad, \& Wingard, 2005). The growth of $R$. salina is shown in Figure 1.

Based on the results of $R$. salina growth curve for 20 days (Figure 1), it was observed that treatment in $\mathrm{C} 1$ culture produced smaller cell density compared to $\mathrm{C} 2$ culture. In both cultures, the growth of $R$. salina were almost at the same point for the first 4 days. However, C1 culture showed different trend, experiencing lag phase before entering the first day. This shows that $R$. salina needs to adapt to high salinity, because it comes from a smaller volume batch with different salinity. Both cultures showed similar growth profile, reaching maximum growth on day 8 and beginning to decrease afterwards.

The maximum cell density in salinity $33 \%$ o $(8.4 \mathrm{x}$ $10^{5} \mathrm{cell} / \mathrm{s} / \mathrm{mL}$ ) was 1.3 times higher than the maximum cell density in salinity $50 \%$ o $\left(6.4 \times 10^{5}\right.$ cells $\left./ \mathrm{mL}\right)$. The maximum growth rate of $R$. salina in culture C2 (0.2 day $^{-1}$ ) was also 1.7 times higher than that of culture C1 $\left(0.12\right.$ day $\left.^{-1}\right)$. Then, the growth was descending of about $2.27 \times 10^{5} \mathrm{cells} / \mathrm{mL}$ and $2.31 \times 10^{5} \mathrm{cells} / \mathrm{mL}$ in margin in cultures $\mathrm{C} 2$ and $\mathrm{C} 1$, respectively, between day 8 and 12 of growth. However, entering on day 16, the growth showed an increase in cell density in culture C2 $\left(6.08 \times 10^{5}\right.$ cells $/ \mathrm{mL}$ to $6.61 \times 10^{5}$ cells/ $\mathrm{mL})$ and culture $\mathrm{C} 1\left(4.07 \times 10^{5} \mathrm{cells} / \mathrm{mL}\right.$ to $5.05 \times 10^{5}$ cells $/ \mathrm{mL}$ ) and the growth dropped eventually to cell death phase at day 20 .

In this experiment setup, the nutrient availability in the culture medium is considered as nutrient deficiency culture (Vu et al., 2015). The $R$. salina growth was depending on the nutrient availability since

Table 1. Experimental conditions of $R$. salina culture

\begin{tabular}{clcc}
\hline Culture & Growth Media & Salinity & Medium \\
\hline C1 & Natural sea water (modified) & $50 \% \circ$ & $\mathrm{f} / 2$ \\
C2 & Natural sea water & $33 \% \circ$ & $\mathrm{f} / 2$ \\
& & & \\
\hline
\end{tabular}




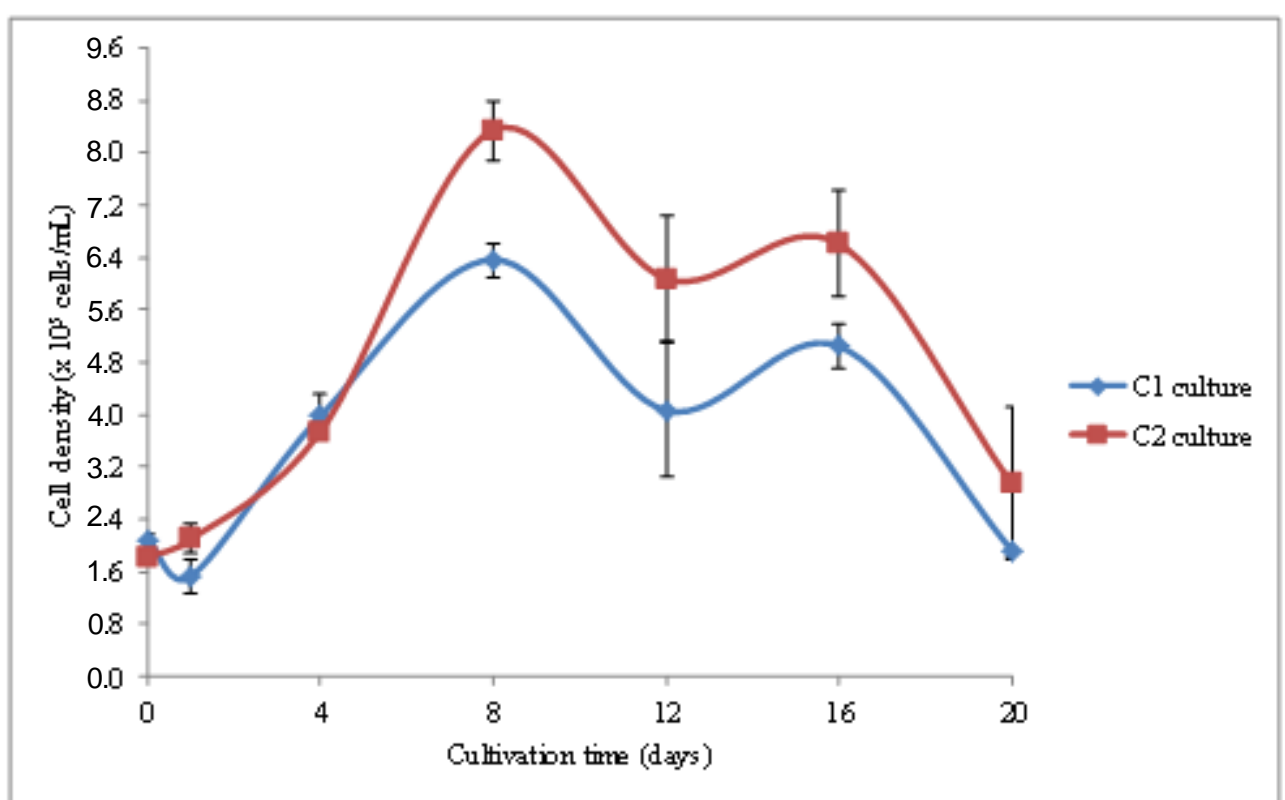

Figure 1. Curve of $R$. salina growth for 20 days. C1 culture (50\% salinity) is represented in blue( $\bullet$ ) and C2 culture $(33 \%$ salinity) is represented in red( $\square)$. Symbols represent means $\pm S D(n=3)$.

the first day of inoculation. According to previous studies, nutrient availability, and irradiance are two environmental factors responsible for Rhodomonas sp. growth (Chaloub et al., 2015; Lafarga-De la Cruz et al.,2006; Vu et al., 2015). Both factors directly influence microalgae growth during the logarithmic phase. Then, beyond the latter phase, the microalgae growth is influenced only by nutrient availability (Lafarga-De la Cruz et al., 2006).

In this experiment, an elevated nitrate concentration of about $1100 \mu \mathrm{M}$ was added and irradiance of 1100 lux (equal to approximately 14.85 $\mu \mathrm{mol}$.photon. $\mathrm{m}^{-2} \mathrm{~s}^{-1}$ ) was applied. According to Chaloub et al. (2015), the optimal nitrate concentration and irradiance for $R$. salina's growth and phycoeryhtrin production are $1100 \mu \mathrm{M}$ and $15 \mu \mathrm{mol}$.photon. $\mathrm{m}^{-2} \mathrm{~s}^{-1}$, respectively. However, the maximum cell density and maximum growth rate of $R$. salina were reached on the $8^{\text {th }}$ day of culture for culture $\mathrm{C} 2$. The maximum growth rate in culture $\mathrm{C} 2\left(0.2\right.$ day $\left.^{-1}\right)$ was higher than that of in culture $C 1\left(0.12\right.$ day $\left.^{-1}\right)$, suggesting that salinity influences microalgae growth.

The highest growth rate of the cryptophyte microalgae ever reached was 1.2 day $^{-1}$ by Pyrenomonas salina (a taxonomic synonym of $R$. salina)(Lewitus \& Caron, 1990). The high growth rate obtained by Lewitus and Caron (1990) is most probably due to the use of ammonium ion as the nitrogen source. While in this study we used nitrate ion as the nitrogen source. Nitrogen is an important macroelement in key molecules such as amino acids for microalgae. When microalgae cell assimilates nitrate ion, it will be reduced into nitrite and ammonium. Eventually the latter will be incorporated into carbon skeletons to form glutamate in an enzymatic process (Sanz-Luque, Chamizo-Ampudia, Llamas, Galvan, \& Fernandez, 2015).

\subsection{Phycoerythrin Production}

We extracted the pigment based on Lawrenz et al. (2011). Figure 2 shows the maximum absorption of phycoeryhtrin at $546 \mathrm{~nm}$. Cryptophyte-phycoerythrin has a maximum absorption in a range of $540-550 \mathrm{~nm}$ (Toole \& Allnutt, 2003).

Figure 3 shows PE concentration produced by $R$. salina during 20 days of growth. All treated cultures showed the same profile across the elapsed days, although they did not share the same PE concentration. In our study, we obtained the highest PE content on day 16th for all treated cultures, 0.22 $\mu \mathrm{g} \cdot 10^{-5} \mathrm{cell}$ for culture $\mathrm{C} 1$ and $0.27 \mu \mathrm{g} \cdot 10^{-5} \mathrm{cell}$ for culture C2 (Figure 3). ANOVA analysis showed that there was no significant difference on phycoerythrin concentration between culture $\mathrm{C} 1$ and culture $\mathrm{C} 2$ ( $p>0.05 ; a=0.05$ ). In the previous study, the maximum PE concentration $\left(1.4 \mu \mathrm{g} \cdot 10^{-5} \mathrm{cell}\right)$ was obtained on day 8 with the following culture conditions, i.e. light irradiance of $15 \mu \mathrm{mol}$.photon. $\mathrm{m}^{-2} \mathrm{~s}^{-1}$ and culture temperature of $26^{\circ} \mathrm{C}$ (Chaloub et al., 2015).

In accordance to the growth curve (Figure 1), the log phase was reached at day 8 , but the PE concentration actually increased until day 16 . The biosynthesis of PE also depends on the availability of 


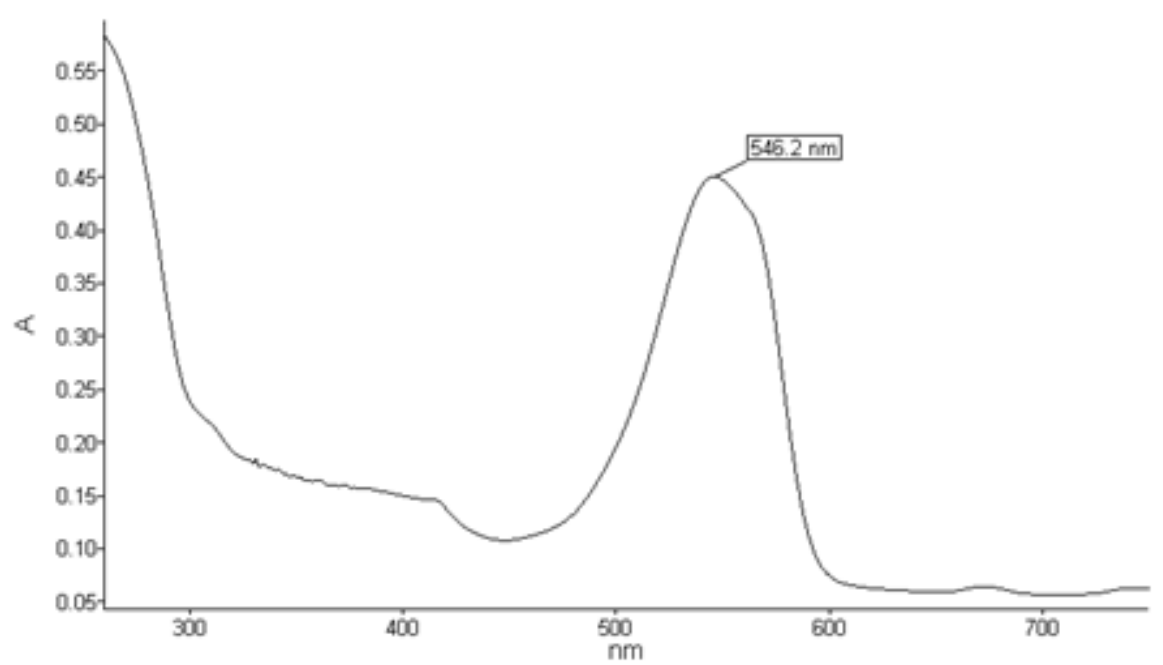

Figure 2. The maximum absorption observed in phycoerythrin crude extract produced by $R$. salina.

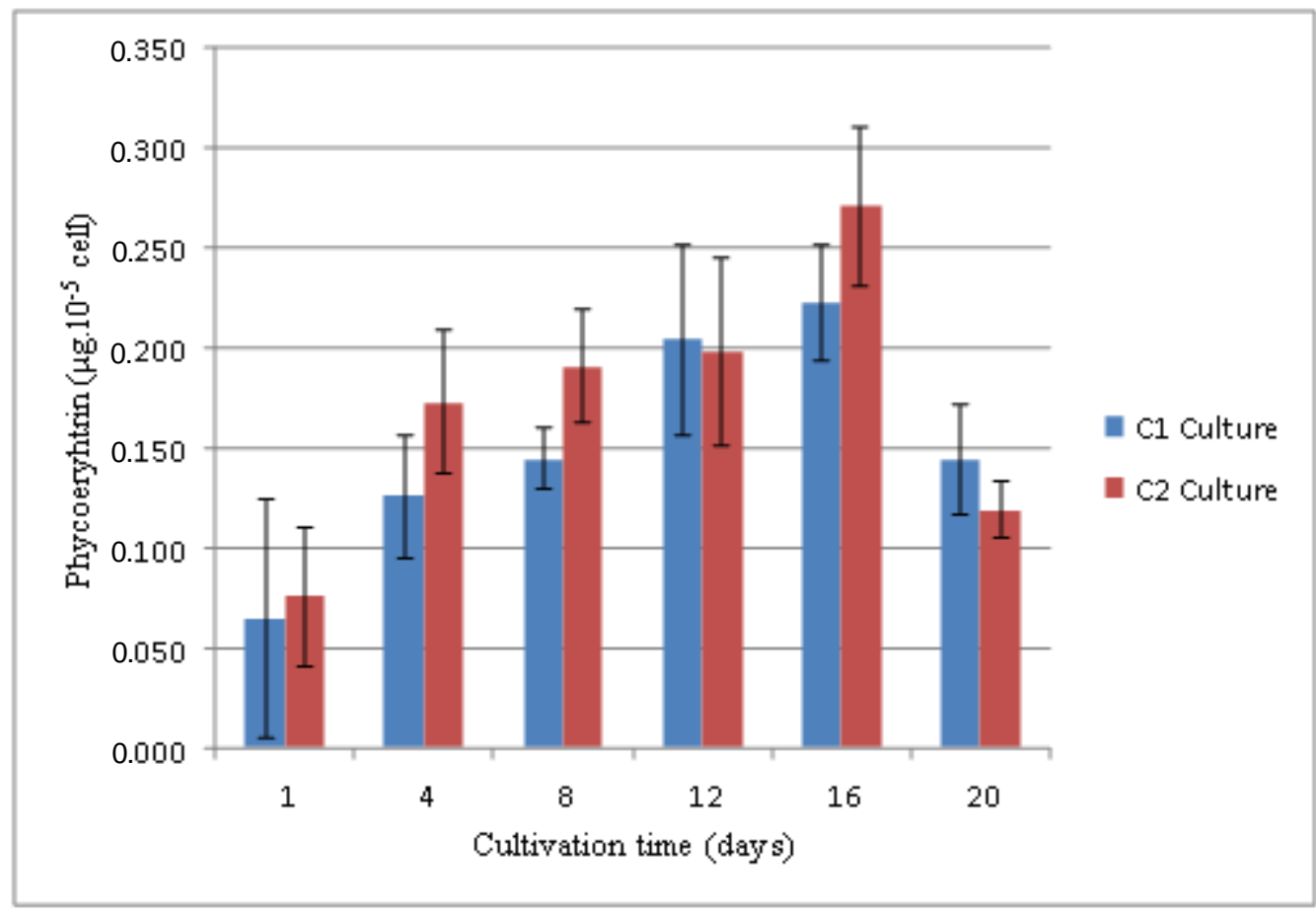

Figure 3. Phycoerythrin concentration observed in $R$. salina culture during 20 days observation. $C 1$ culture in blue bars and $\mathrm{C} 2$ culture in red bars. The data represent means of three independent experiments $(n=3)$.

nitrogen in the growth medium. da Silva et al. (2009) revealed that the initial nitrate ion in Rhodomonas sp. culture medium decreased up to $70 \%$ during the first 4 days of cultivation. However, the $R$. salina growth did not show a decline in the growth curve after day 4 and/or even between day 12 to day 16 (Figure 1). According to Bartual et al. (2002), it is believed that the PE degradation is a survival mechanism for sustaining cellular growth and/or maintenance in a nutrient short supply medium. At this degradation process, PE is mobilizing its nitrogen to cope nitrogen shortage.

Previous studies have revealed that nutrients which directly affect the content of photosynthetic microalgae pigments are nitrate and phosphate (da Silva et al., 2009; Lewitus \& Caron, 1990). In conjunction with its cellular composition, the presence of nitrogen has a role in the biosynthesis of PE (Chaloub et al., 2015). In addition, besides functioning as a light-harvesting apparatus, PE also serves as a source of nitrogen 
reserves in Rhodomonas sp. cells (da Silva et al., 2009; Lewitus \& Caron, 1990). The results of this study reinforce the aforementioned theory. This was observed in the microalgae growth curve as it enters the stationary phase or from day 12 to day 16 (Figure 1) that the cell density is inversely proportional to the concentration of PE (Figure 3).

\section{Conclusion}

Rhodomonas salina was able to adapt to wide range of saline environment. $R$. salina obtained the cell density in $\mathrm{C} 1$ culture of $8.4 \times 10^{5}$ cells $/ \mathrm{mL}$ and PE concentration of $0.19 \mu \mathrm{g}$. $10^{-5}$ cell on day 8 , however it reached the highest PE concentration of $0.27 \mu \mathrm{g} .10^{-5}$ cell on day 16 of the culture. There was no significant difference on growth and phycoerythrin concentration produced by $R$. salina that was cultivated in $33 \%$ o salinity and $50 \%$ o salinity ( $p>0.05$; $\alpha=0.05$ ).

\section{Acknowledgment}

This research was funded by the Ministry of Marine Affairs and Fisheries through APBN year 2016. We thank Prof. Dr. Haryanti, MS, from Institute for Mariculture Research and Fisheries Extension (IMRAFE), Gondol, Bali for providing of $R$. salina cell.

\section{References}

Andersen, R. A., Berges, J. A., Harrison, P. J., \& Watanabe, M. M. (2005). Recipes for freshwater and seawater media. In R. A. Andersen (Ed.), Algal culturing techniques (pp. 429-538). Oxford: Elsevier Academic Press.

Bartual, A., Lubián, L. M., Gálvez, J. A., \& Niell, F. X. (2002). Effect of irradiance on growth, photosynthesis, pigment content and nutrient consumption in dense cultures of Rhodomonas salina (Wislouch) (Cryptophyceae) Efecto de la irradiancia en el crecimiento, fotosíntesis, contenido pigmentario y consumo de. Ciencias Marinas, 28(4), 381-392.

Chaloub, R. M., Motta, M. N. S., de Araujo, S. P., de Aguiar, P. F., \& da Silva, A.F. (2015). Combined effects of irradiance, temperature and nitrate concentration on phycoerythrin content in the microalga Rhodomonas sp. (Cryptophyceae). Algal, 8, 89-94. doi: 10.1016/ j.algal.2015.01.008

da Silva, A. F., Lourenco, S. O., \& Chaloub, R. M. (2009). Effects of nitrogen starvation on the photosynthetic physiology of a tropical marine microalga Rhodomonas sp . (Cryptophyceae). Aquatic Botany, 91, 291-297. doi: 10.1016/j.aquabot.2009.08.001

de Marsac, N. T. (2003). Phycobiliproteins and phycobilisomes: the early observations. Photosynthesis Research, 76(1-3), 193-205. doi: 10.1023/A:1024954911473
Jepsen, P. M., Thoisen, C. V., Carron-Cabaret, T., PinyolGallemí, A., Nielsen, S. L., \& Hansen, B. W. (2018). Effects of salinity, commercial salts, and water type on cultivation of the Cryptophyte microalgae Rhodomonas salina and the Calanoid copepod Acartia tonsa. Journal of the World Aquaculture Society. doi:10.1111/jwas.12508

Lafarga-De la Cruz, F., Valenzuela-Espinoza, E., MillanNunez, R., Trees, C. C., Santamarýa-del-Angel, E., \& Nunez-Cebrero, F. (2006). Nutrient uptake, chlorophyll $a$ and carbon fixation by Rhodomonas sp. (Cryptophyceae) cultured at different irradiance and nutrient concentrations. Aquacultural Engineering, 35, 51-60. doi: 10.1016/j.aquaeng.2005.08.004

Lamers, P. P., Janssen, M., De Vos, R. C. H., Bino, R. J., \& Wijfels, R. H. (2008). Exploring and exploiting carotenoid accumulation in Dunaliella salina for cellfactory applications. Trends in Biotechnology, 26(11), 631-638. doi: 10.1016/j.tibtech.2008.07.002

Lawrenz, E., Fedewa, E. J., \& Richardson, T. L. (2011). Extraction protocols for the quantification of phycobilins in aqueous phytoplankton extracts. Journal of Applied Phycology, 865-871. doi: 10.1007/ s10811-010-9600-0

Lee, R. E. (2008). Phycology (Fourth Edi). New York: Cambridge University Press. doi: 10.1017/ CBO9780511812897.002

Lewitus, A. J., \& Caron, D. A. (1990). Relative effects of nitrogen or phosphorus depletion and light intensity on the pigmentation, chemical composition, and volume of Pyrenomonas salina (Cryptophyceae). Marine Ecology Progress Series, 61, 171-181.

Mulders, K. J. M., Lamers, P. P., Martens, D. E., \& Wijffels, H. (2014). Phototrophic pigment production with microalgae/ : biological constraints and opportunities. Journal of Phycology, 50, 229-242. doi: 10.1111/jpy. 12173

Sanz-Luque, E., Chamizo-Ampudia, A., Llamas, A., Galvan, A., \& Fernandez, E. (2015). Understanding nitrate assimilation and its regulation in microalgae. Frontiers in Plant Science, 6:899. doi: 10.3389/ fpls.2015.00899

Thoisen, C., Hansen, B. W., \& Nielsen, S. L. (2017). A simple and fast method for extraction and quantification of cryptophyte phycoerythrin. Methods $X, 4,209-213$. doi: 10.1016/j.mex.2017.06.002

Toole, C. M., \& Allnutt, F. C. T. (2003). Red, cryptomonad and glaucocystophyte algal phycobiliproteins. In A. W. D. . Larkum, S. E. . Douglas, \& J. A. Raven (Eds.), Photosynthesis in Algae (pp. 305-334). Dordrecht: Kluwer Academic Publishers.

Vu, M. T. T., Douëtte, C., Rayner, T. A., Thoisen, C., Nielsen, S. L., \& Hansen, B. W. (2015). Optimization of photosynthesis, growth, and biochemical composition of the microalga Rhodomonas salina - an established diet for live feed copepods in aquaculture. Journal of Applied Phycology. doi: 10.1007/s10811-015-0722-2

Wood, A. M., Everroad, R. C., \& Wingard, L. M. (2005). Measuring growth rates in microalgal cultures. In $\mathrm{R}$. A. Andersen (Ed.), Algal Culturing Techniques (pp. 269-285). Oxford: Elsevier Academic Press. 